\title{
In vitro synergistic, antagonistic, and duration of exposure effects of metal cations on eukaryotic cells
}

\author{
J.C. Wataha; C.T. Hanks, and R.G. Craig \\ The University of Michigan School of Dentistry, Ann Arbor, Michigan 48109-1078
}

Effects of duration of exposure of single metal cations $\left(\mathrm{Ag}^{+1}, \mathrm{Cd}^{+2}, \mathrm{Cu}^{+2}, \mathrm{Ga}^{+3}, \mathrm{Ni}^{+2}\right.$, and $\left.\mathrm{Zn}^{+2}\right)$ on ${ }^{3} \mathrm{H}$-thymidine $\left({ }^{3} \mathrm{H}-\mathrm{Td} \mathrm{r}\right)$ incorporation and 3-[4,5-dimethylthiazol-2yl-]-2,5-diphenyl tetrazolium bromide-formazan (MTT-f) production in cultured murine fibroblasts (Balb/c 3T3) were investigated, and the synergistic and antagonistic effects of two metal cations applied simultaneously to the fibroblasts were assessed. The effects of duration of exposure were quantified using TC50 values (concentration of an element required to cause $50 \%$ toxicity compared with controls) measured after 24,48 , or $72 \mathrm{~h}$. Using MT T-f production, $\mathrm{Cd}^{+2}$, $\mathrm{Cu}^{+2}, \mathrm{Ga}^{+3}$, and $\mathrm{Ni}^{+2}$ showed significantly lower TC50 values with increasing time of exposure, whereas the TC50 values for $\mathrm{Ag}^{+1}$ and $\mathrm{Zn}^{+2}$ remained constant. The TC50 values using ${ }^{3} \mathrm{H}-\mathrm{Td}$ incorporation exhibited a similar pattern with time of exposure, but the effects were less pronounced. The TC50 values for ${ }^{3} \mathrm{H}-\mathrm{Td} \mathrm{r}$ and MTT-f tended to equalize at $72 \mathrm{~h}$. All combinations of cations tested (Ag-Cu, Ag-Zn, Ag-Ni, Cu-Zn, Cu-Ni, Ga-Ni, and $\mathrm{Cu}-\mathrm{Cd}$ ) exhibited synergistic and antagonistic effects as measured by MTT-f production. Synergistic and antagonistic effects were not necessarily mutually exclusive in the same system. (c) 1992 John Wiley \& Sons, Inc.

\section{INTRODUCTION}

Previous studies have established that metallic elements can be released from dental casting alloys, ${ }^{1-5}$ amalgams, ${ }^{6-8}$ or cements, ${ }^{9,10}$ and the in vitro cytotoxicities of these elements have been assessed. ${ }^{11-14}$ However, the in vitro effects of varying the duration of exposure of these elements to cultured cells or of testing two elements simultaneously remains largely unexplored.

The purposes of the current study were (a) to investigate the effects of duration of exposure effects of single metal cations on the ${ }^{3} \mathrm{H}$-thymidine $\left({ }^{3} \mathrm{H}\right.$ Tdr) incorporation and 3-[4,5-dimethyl-thiazol-2yl-]-2,5-diphenyl tetrazolium bromide (MTT-f) production on cultured murine fibroblasts, and (b) to assess synergistic or antagonistic effects when two metal cations were applied to fibroblasts simultaneously. Knowledge of these effects should allow more relevant construction of in vitro tests designed to assess biomaterials which release these cations, and may provide insight into the mechanisms of toxicity exerted by these biomaterials.

*To whom correspondence should be addressed.

Journal of Biomedical Materials Research, Vol. 26, 1297-1309 (1992)

(C) 1992 John Wiley \& Sons, Inc.

CCC 0021-9304/92/101297-13\$4.00 


\section{MATERIALS AND METHODS}

\section{Duration of exposure}

Six metal cations were studied: $\mathrm{Ag}^{+1}, \mathrm{Cd}^{+2}, \mathrm{Cu}^{+2}, \mathrm{Ga}^{+3}, \mathrm{Ni}^{+2}$, and $\mathrm{Zn}^{+2}$. These cations were chosen because of their tendency to be released from dental biomaterials. Sources, purities, and preparation methods of these cations have been described previously. ${ }^{14}$ Aqueous solutions of these cations were prepared such that addition of $20 \mu \mathrm{L}$ of a solution to $1.0 \mathrm{~mL}$ of cell culture medium would provide the desired final concentration. Six concentrations of each metal cation were used (Table I). Concentrations were chosen empirically such that the maximum concentration caused complete cytotoxicity after $24 \mathrm{~h}$.

Balb/c 3T3 mouse fibroblasts (ATCC/CCL 163, clone A31) were harvested from preconfluent flasks and plated using $1.0 \mathrm{~mL} /$ well in 24-well tissue culture trays. Experimental cell culture medium consisted of Dulbecco's Modified Eagle's Medium without glutamine (DMEM), 3\% NuSerum, $28 \mathrm{mM}$ HEPES ( $N$-2-hydroxyethylpiperazine- $N^{\prime}$-2-ethanesulfonic acid, $\mathrm{pH}=7.2$ ), penicillin (125 units $/ \mathrm{mL})$, streptomycin $(125 \mu \mathrm{g} / \mathrm{mL})$, gentamycin $(10 \mu \mathrm{g} / \mathrm{mL})$, and glutamine $(2 \mathrm{mmol} / \mathrm{L})$. HEPES controlled the $\mathrm{pH}( \pm 0.05 \mathrm{pH}$ units $)$ when metal cations were added. Several minutes after plating, aliquots of $20 \mu \mathrm{L}$ of the metal cation solutions were added to the wells, and the cells were incubated for 24,48 , or $72 \mathrm{~h}$ at $37^{\circ} \mathrm{C}, 5 \% \mathrm{CO}_{2}$ and $100 \%$ relative humidity. No precipitation was observed with any of the metal cation concentrations used. A cell density of 12,500 cells/ $/ \mathrm{cm}^{2}$ was used in experiments which lasted for 24 or $48 \mathrm{~h}$, whereas a cell density of 6250 cells $/ \mathrm{cm}^{2}$ was used in the 72 -h experiments. The density adjustments ensured that the cells would not reach confluence during the tests and provided enough cells for maximum sensitivity. Six replicate wells were plated for each concentration of metal cation. Selected experiments were repeated to ensure reproducibility.

After incubation, the ${ }^{3} \mathrm{H}-\mathrm{Td}$ incorporation or MTT-f production of the cells was measured using methods described previously. ${ }^{14}$ Briefly, ${ }^{3} \mathrm{H}-\mathrm{Tdr}$ incorporation (indicative of DNA synthesis) was assessed by adding ${ }^{3} \mathrm{H}-\mathrm{Td}$ r $45 \mathrm{~min}$ before sacrificing the cells. Scintillation counting was then used to measure the incorporated label. MTT-f production (indicative of succinic dehydrogenase (SDH) activity) was measured by incubating the cells with MTT and disodium succinate over a $90-\mathrm{min}$ period before cell sacrifice. The optical absorption of the formazan salt solubilized in dimethyl sulfoxide (DMSO) was assessed at $560 \mathrm{~nm}$. These two cellular parameters of cytotoxicity were chosen because previous studies had shown that ${ }^{3} \mathrm{H}-\mathrm{Td}$ incorporation was highly sensitive and MTT-f production was moderately sensitive to metal cations. ${ }^{14}$ The $50 \%$ toxicity concentrations $\left(\mathrm{TC}^{2} 0^{\prime} \mathrm{s}=\right.$ concentration required to suppress activity to $50 \%$ of controls) were determined from graphs of concentration vs. activity for each time $(24,48$, or $72 \mathrm{~h}$ ) and each cellular parameter. Errors in the TC50 values were determined graphically and were approximately $10 \%$ at $p=0.05$. 


\section{Synergism and antagonism}

The toxicity of seven binary combinations of metal cations were studied: $\mathrm{Ag}^{+1}-\mathrm{Cu}^{+2}, \mathrm{Ag}^{+1}-\mathrm{Zn}^{+2}, \mathrm{Ag}^{+1}-\mathrm{Ni}^{+2}, \mathrm{Cu}^{+2}-\mathrm{Zn}^{+2}, \mathrm{Cu}^{+2}-\mathrm{Ni}^{+2}, \mathrm{Ga}^{+3}-\mathrm{Ni}^{+2}$, and $\mathrm{Cu}^{+2}-\mathrm{Cd}^{+2}$. These combinations were selected because of their tendencies to be released together from various metals. Aqueous solutions of each metal cation were mixed separately such that $10 \mu \mathrm{L}$ of each solution added to $200 \mu \mathrm{L}$ of cell culture medium gave the desired final concentrations of both cations. Eight concentrations of each cation were used in every experiment. Thus, 64 binary combinations of concentrations of the cations were tested (Table I). Concentrations were chosen to be relevant to those released from dental casting alloys in a previous in vitro study. ${ }^{4}$

Cell-culture techniques were as described in the previous section with the following exceptions. Cells were plated at 20,300 cells $/ \mathrm{cm}^{2}$ using $200 \mu \mathrm{L} /$ well in 96-well tissue culture plates. The cells were incubated for $24 \mathrm{~h}$, then $10-\mu \mathrm{L}$ aliquots of each of the two metal cation solutions were added and the cells were incubated for an additional $24 \mathrm{~h}$. No precipitation was observed in the medium upon addition of the metal cations, and the $\mathrm{pH}$ was stable to within $0.05 \mathrm{pH}$ units. There were eight replicate wells for each of the 64 concentration combinations. Plates with 96 wells were used because of the large numbers of wells required. After incubation, the MTT-f production was evaluated in each well as described earlier.

The mean observed absorbance was calculated for each combination of cations tested, and these absorbances were used to generate an $n$th polynomial best-fit surface against both metal cation concentrations simultaneously. Three-dimensional graphs of expected absorbance vs. the metal cation concentrations were generated based on the assumption that the two cations acted independently (additively). The difference between these two surfaces (observed minus expected) was then plotted. This differential surface represented the deviation of the observed toxicity from the toxicity expected based upon the independent action of each metal cation. If the observed MTT-f production was greater than expected (because there was less cytotoxicity than expected), then the differential graph showed positive values, and indicated an antagonism of the expected toxicity. If the observed MTT-f production was less than expected (because there was greater cytotoxicity than expected), then the differential graph showed negative values, and indicated a synergism of the toxicity of the two cations.

\section{RESULTS}

\section{Duration of exposure}

Figure 1 shows TC50 concentrations when $\mathrm{Cu}^{+2}$ was exposed to cells for 24 , 48 , and $72 \mathrm{~h}$ and is typical of the results when the duration of exposure was changed. The TC50 $0_{\mathrm{MTT} \text {-f }}$ concentrations decreased from over 6 parts per mil- 


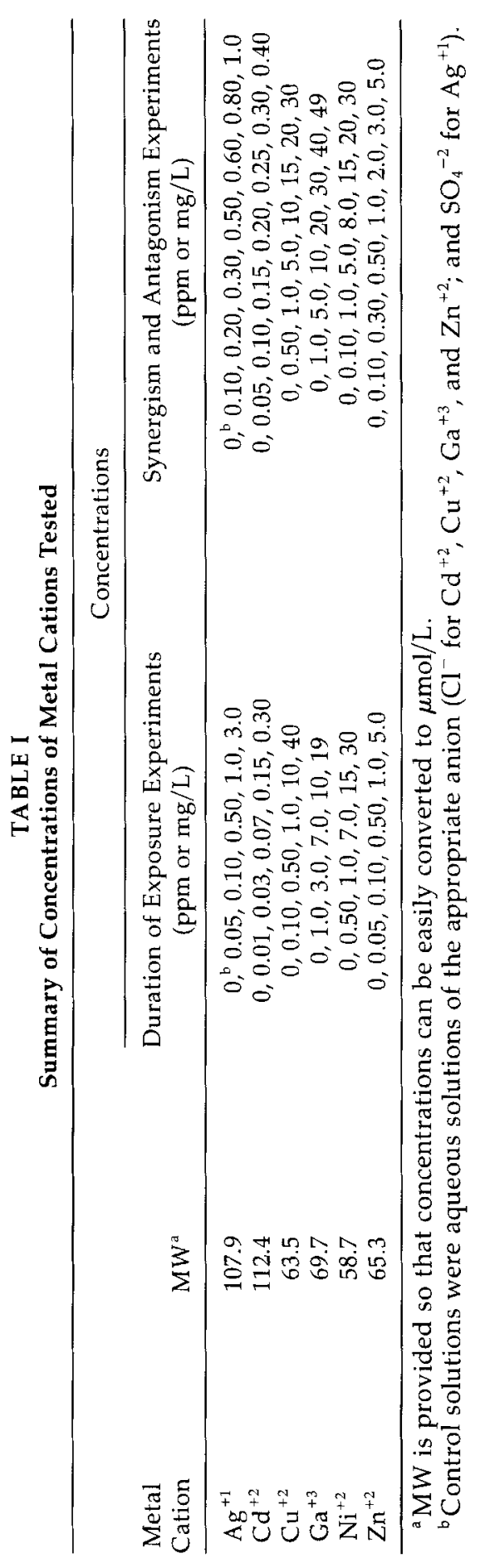




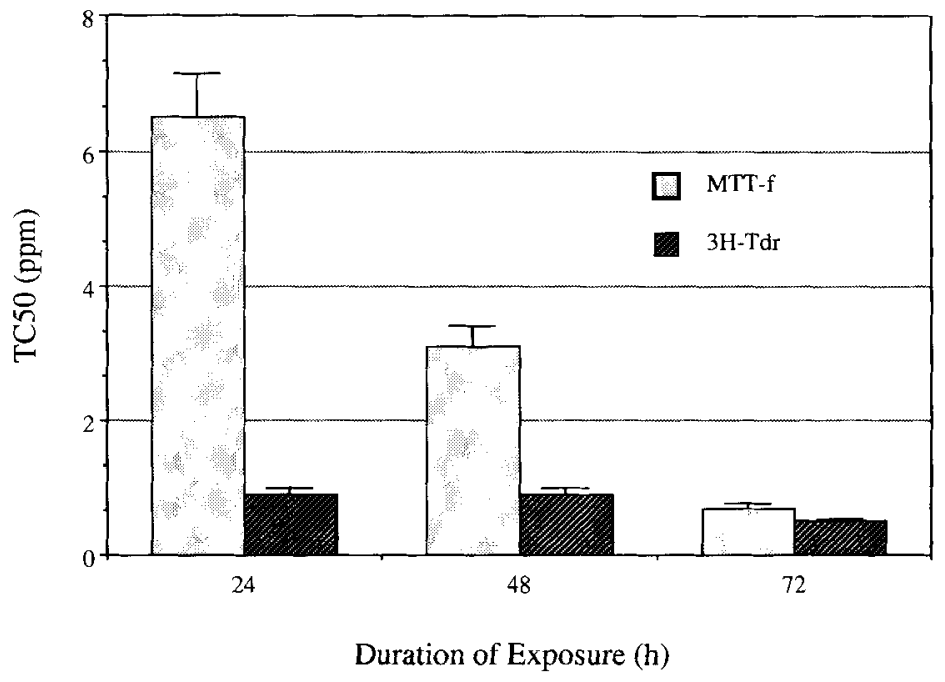

Figure 1. An example, using $\mathrm{Cu}^{+2}$, of the effects of duration of exposure on the TC50 concentrations for ${ }^{3} \mathrm{H}-\mathrm{Td} d \mathrm{r}$ incorporation and MTT-f production.

lion (ppm) to less than $1 \mathrm{ppm}$ as the duration of exposure increased from 24 to $72 \mathrm{~h} .{ }^{3} \mathrm{H}$-Tdr incorporation also decreased with increased duration of exposure but this effect was less pronounced. The disparity among the TC50 values for ${ }^{3} \mathrm{H}-\mathrm{Tdr}$ incorporation and MTT-f production at $24 \mathrm{~h}$ was therefore reduced at $72 \mathrm{~h}$. Table II summarizes the duration of exposure data for all six elements. Effects similar to those for $\mathrm{Cu}^{+2}$ (Fig. 1) were evident with $\mathrm{Cd}^{+2}$, $\mathrm{Ga}^{+3}$, and $\mathrm{Ni}^{+2}$, although the disparity at $24 \mathrm{~h}$ between ${ }^{3} \mathrm{H}-\mathrm{Td}$ incorporation and MTT-f was greatest for $\mathrm{Cu}^{+2} \cdot \mathrm{Ag}^{+1}$ and $\mathrm{Zn}^{+2}$ did not show decreased TC50 concentrations with exposures up to $72 \mathrm{~h}$ for either ${ }^{3} \mathrm{H}$-Tdr incorporation or MTT-f production. The TC50 values appeared to increase slightly for $\mathrm{Ag}^{+1}$, but this trend was not significant statistically.

\section{Synergistic and antagonistic effects}

The observed, expected, and differential MTT-f production for the $\mathrm{Ag}^{+1}-$ $\mathrm{Cu}^{+2}$ system are shown in Figures 2(a), 2(b), and 2(c), respectively. Some differences between the observed and expected surfaces are discernible in Figures 2(a) and 2(b), but the differential surface clearly shows where deviation from the expected values occurred. In this system, MTT-f production was greater than expected when $\mathrm{Cu}^{+2}$ ranged between 0 and $10 \mathrm{ppm}$ and $\mathrm{Ag}^{+1}$ ranged between 0.2 and $1.0 \mathrm{ppm}$. Thus the toxicity caused by these cations was less than expected indicating an antagonism of the toxic effect relative to the expected effect if the cations acted additively. The error bars represent three standard errors of the mean ( 3 SEM) and indicate $95 \%$ confidence intervals for the surfaces.

Figures 3 and 4 show differential graphs for the other six combinations of metal cations tested. The $z$-axis represents MTT-f production, whereas the $x$ 
TABLE II

$50 \%$ Toxicity Concentrations (TC50's) in ppm and $\mu \mathrm{M}$ for MTT-f Production and $3 \mathrm{H}-\mathrm{Tdr}$ Incorporation for 24-, 48-, and 72-h Exposures

\begin{tabular}{|c|c|c|c|c|c|c|}
\hline \multirow[b]{3}{*}{ Cation } & \multicolumn{6}{|c|}{ Duration of Exposure } \\
\hline & \multicolumn{2}{|c|}{$24 \mathrm{~h}$} & \multicolumn{2}{|c|}{$48 \mathrm{~h}$} & \multicolumn{2}{|c|}{$72 \mathrm{~h}$} \\
\hline & ppm & $\mu \mathrm{M}$ & ppm & $\mu \mathrm{M}$ & $\mathrm{ppm}$ & $\mu \mathrm{M}$ \\
\hline \multicolumn{7}{|l|}{$\mathrm{Ag}^{+1}$} \\
\hline MTT-f & 0.72 & 6.7 & 0.70 & 6.5 & 0.80 & 7.4 \\
\hline${ }^{3} \mathrm{H}-\mathrm{Tdr}$ & 0.67 & 6.2 & 0.67 & 6.2 & 0.88 & 8.2 \\
\hline \multicolumn{7}{|l|}{$\mathrm{Cd}^{+2}$} \\
\hline MTT-f & 0.42 & 3.7 & 0.11 & 1.0 & 0.05 & 0.4 \\
\hline${ }^{3} \mathrm{H}-\mathrm{Td} \mathrm{r}$ & 0.15 & 1.3 & 0.08 & 0.7 & 0.05 & 0.4 \\
\hline \multicolumn{7}{|l|}{$\mathrm{Cu}^{+2}$} \\
\hline MTT-f & 6.5 & 102 & 3.1 & 49 & 0.7 & 11 \\
\hline${ }^{3} \mathrm{H}-\mathrm{Td} r$ & 0.9 & 14 & 0.9 & 14 & 0.5 & 7.8 \\
\hline \multicolumn{7}{|l|}{$\mathrm{Ga}^{+3}$} \\
\hline MTT-f & 2.0 & 29 & 0.7 & 10 & 0.4 & 5.7 \\
\hline${ }^{3} \mathrm{H}-\mathrm{Td} \mathrm{r}$ & 1.0 & 14 & 0.6 & 8.6 & 0.5 & 7.1 \\
\hline \multicolumn{7}{|l|}{$\mathrm{Ni}^{+2}$} \\
\hline MTT-f & 22 & 370 & 7 & 120 & 2.1 & 36 \\
\hline${ }^{3} \mathrm{H}-\mathrm{Tdr}$ & 11 & 190 & 4 & 68 & 1.3 & 22 \\
\hline \multicolumn{7}{|l|}{$\mathrm{Zn}^{+2}$} \\
\hline MTT-f & 2.3 & 35 & 2.1 & 32 & 2.0 & 31 \\
\hline${ }^{3} \mathrm{H}-\mathrm{Tdr}$ & 2.3 & 35 & 2.1 & 32 & 1.9 & 29 \\
\hline
\end{tabular}

Errors are approximately $10 \%, p=0.05$.

Cell target: 25,000 cells $(24,48 \mathrm{~h}), 12,000$ cells $(72 \mathrm{~h})$. Cell density: $12,500 \mathrm{cells} / \mathrm{cm}^{2}(24$, $48 \mathrm{~h}), 6250 \mathrm{cells} / \mathrm{cm}^{2}(72 \mathrm{~h})$. Metal cations were added immediately after plating.

and $y$ axes represent concentrations of the metal cations in ppm. Synergistic effects were observed with the $\mathrm{Cd}^{+2}-\mathrm{Cu}^{+2}, \mathrm{Ni}^{+2}-\mathrm{Cu}^{+2}$, and $\mathrm{Zn}^{+2}-\mathrm{Cu}^{+2}$ systems [Figs. 3(a), 3(b), and 3(c), respectively]. These effects always occurred when the $\mathrm{Cu}^{+2}$ concentration was between 0 and $10 \mathrm{ppm}$. The differential surfaces for $\mathrm{Ag}^{+1}-\mathrm{Zn}^{+2}, \mathrm{Ag}^{+1}-\mathrm{Ni}^{+2}$, and $\mathrm{Ga}^{+3}-\mathrm{Ni}^{+2}$ were more complex. The $\mathrm{Ag}^{+1}-\mathrm{Ni}^{+2}$ and $\mathrm{Ni}^{+2}-\mathrm{Ga}^{+3}$ systems [Figs. 4(b) and 4(c), respectively] exhibited both areas of synergism and antagonism, whereas the $\mathrm{Ag}^{+1}-\mathrm{Zn}^{+2}$ system [Fig. 4(a)] showed a small but significant bimodal antagonism.

Table III summarizes the interactive effects for the seven combinations of metal cations. The presence of $\mathrm{Ag}^{+1}$ was invariably associated with antagonism in the system, whereas the presence of $\mathrm{Cu}^{+2}$ seemed to promote synergism except in the $\mathrm{Ag}^{+1}-\mathrm{Cu}^{+2}$ system. The $\mathrm{Ag}^{+1}-\mathrm{Ni}^{+2}$ and $\mathrm{Ga}^{+3}-\mathrm{Ni}^{+2}$ systems showed both synergistic and antagonistic effects, demonstrating that these effects were not necessarily mutually exclusive in the same system.

\section{DISCUSSION}

The observation that TC50 values can be a function of the duration of exposure was not surprising, but does imply that the duration of exposure 
(a)

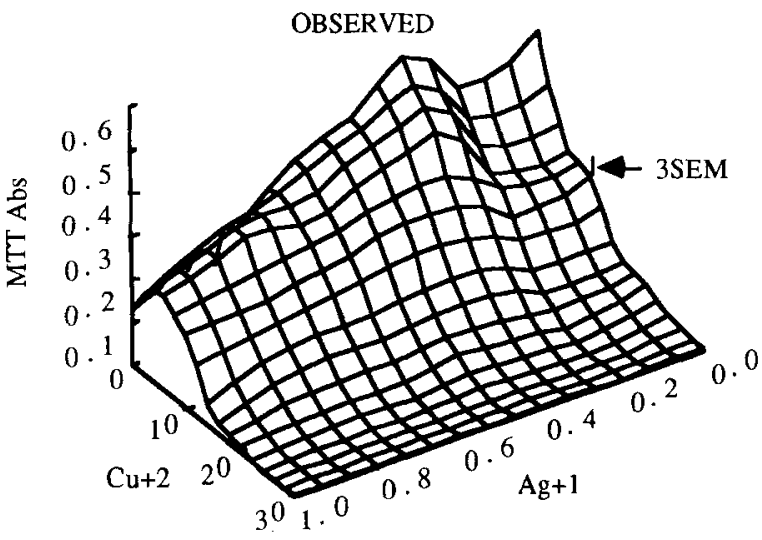

(b)

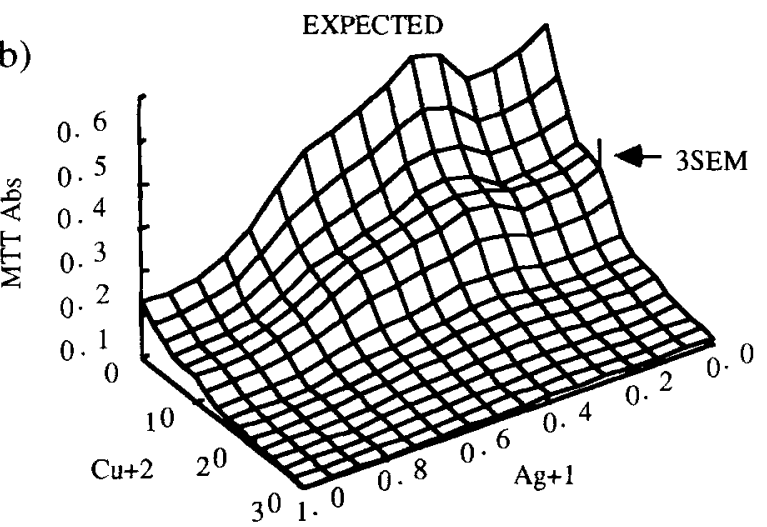

(c) DIFFERENTIAL (OBSERVED - EXPECTED)

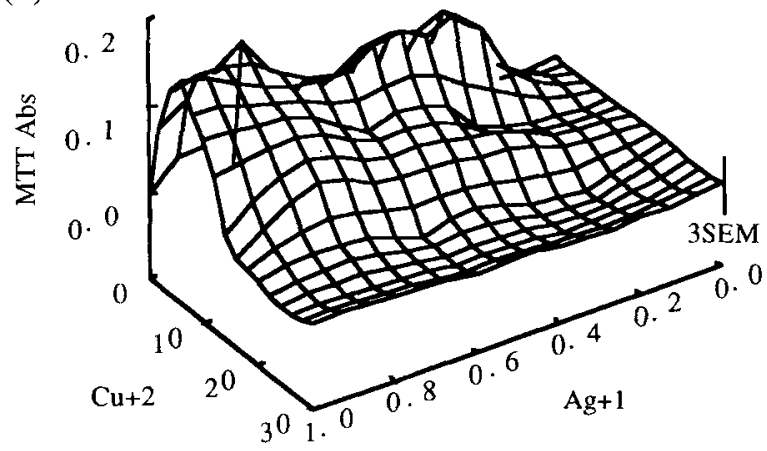

Figure 2. An example of the effects of $\mathrm{Ag}^{+1}$ and $\mathrm{Cu}^{+2}$ concentration on MTT-f production after $24-\mathrm{h}$ exposure duration. The cell target was 6700 cells at 20,300 cells $/ \mathrm{cm}^{2}$, cation concentrations are in ppm, MTT-f production is in optical density (OD) units, and the error bars represent a $95 \%$ confidence interval for the surface $(p=0.05)$. (a) Observed levels of MTT-f production. (b) Expected levels of MTT-f production based on the assumption of additive toxicities of each of the cations. (c) The difference between observed and expected effects (differential surface) illustrating concentrations at which the two cations interacted in a nonadditive manner. 
(a)

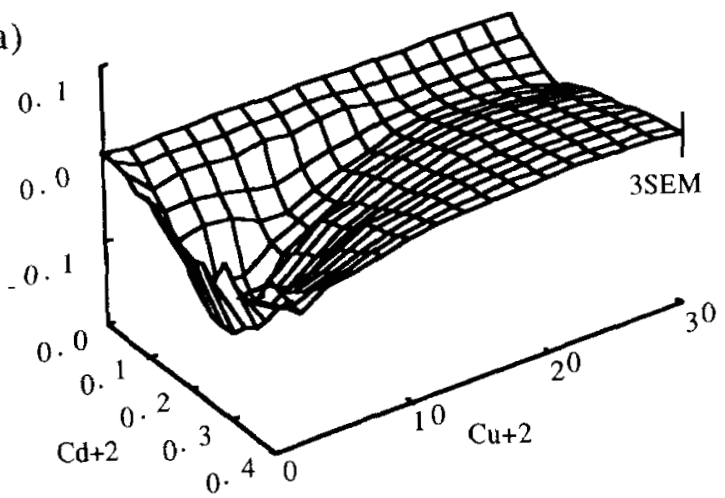

(b)
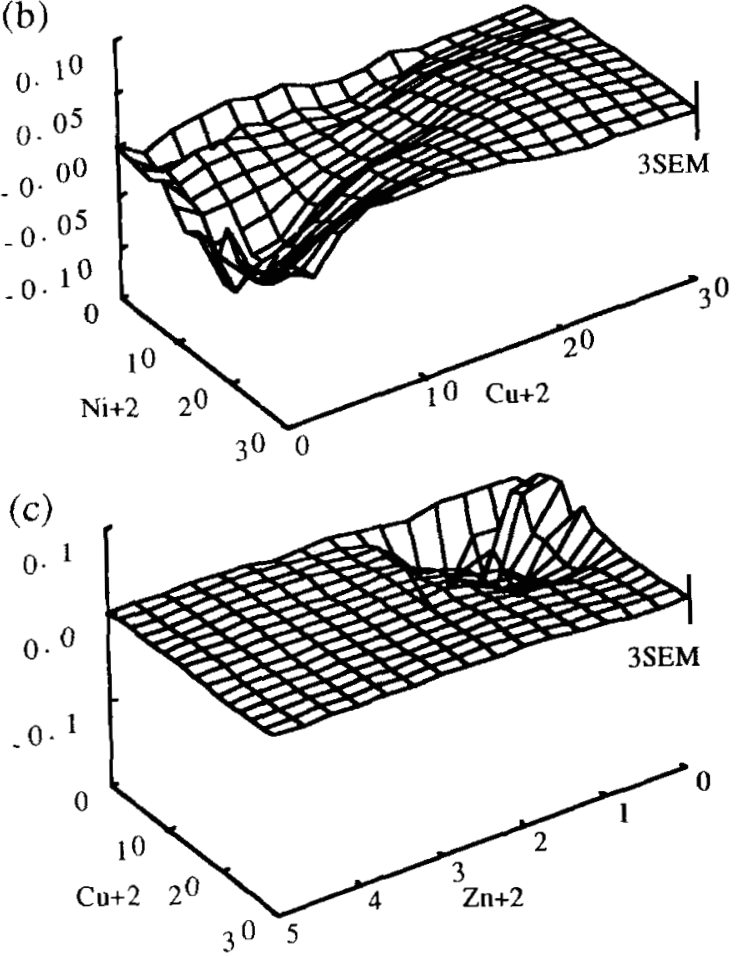

Figure 3. The differential surfaces for MTT-f production (OD units) plotted vs. cation concentrations (ppm) for several cation combinations. MTT-f production is plotted on the $z$ axis, whereas cation concentrations in ppm are plotted on the $x$ and $y$ axes. Error bars at $p=0.05$. Significant synergistic effects observed with the (a) $\mathrm{Cd}^{+2}-\mathrm{Cu}^{+2}$, (b) $\mathrm{Ni}^{+2}-\mathrm{Cu}^{+2}$, and (c) $\mathrm{Zn}^{+2}$ $\mathrm{Cu}^{+2}$ systems.

should be carefully considered when developing an in vitro test to assess the cytotoxicity of biomaterials which might release these metal cations. The ${ }^{3} \mathrm{H}$ $\mathrm{Tdr}$ incorporation was less dependent upon duration of exposure but changed significantly from 24- to 72-h exposures (Table II). However, the observation that the TC50's for ' $\mathrm{H}-\mathrm{Td}$ r incorporation and MTT-f production tended to equalize after $72 \mathrm{~h}$ indicated that the ${ }^{3} \mathrm{H}-\mathrm{Td}$ r would be a good pre- 

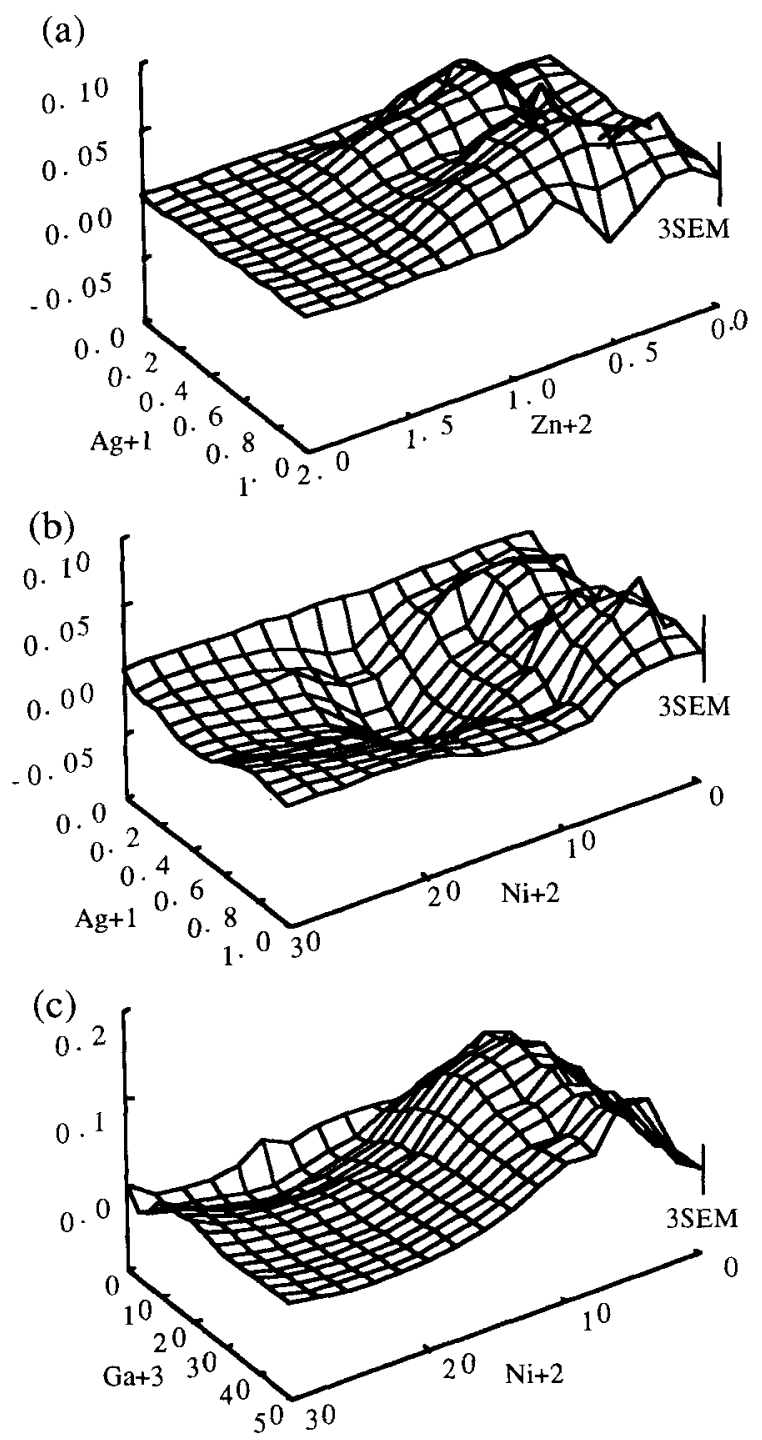

Figure 4. The differential surfaces for MTT-f production vs. cation concentrations for $\mathrm{Ag}^{+1}-\mathrm{Zn}^{+2}, \mathrm{Ag}^{+1}-\mathrm{Ni}^{+2}$, and $\mathrm{Ni}^{+2}-\mathrm{Ga}^{+3}$. (a) Small but significant bimodal antagonism in the $\mathrm{Ag}^{+1}-\mathrm{Zn}^{+2}$ system. (b) Both synergism and slight antagonism (not significant) in the $\mathrm{Ag}^{+1}-\mathrm{Ni}^{+2}$ system. (c) Significant synergism and antagonism in the $\mathrm{Ni}^{+2}-\mathrm{Ga}^{+3}$ system.

dictor of 72-h cytotoxicity if a shorter duration of exposure was desirable or necessary because of experimental constraints.

$\mathrm{Ag}^{+1}$ and $\mathrm{Zn}^{+2}$ did not exhibit decreased TC50 values with longer durations of exposure. It is not known whether this independence was caused by different mechanisms of toxicity of these cations, or a difference in the rate of toxicity development. It is possible that the decrease in TC 50 values observed for $\mathrm{Cd}^{+2}, \mathrm{Cu}^{+2}, \mathrm{Ga}^{+3}$ and $\mathrm{Ni}^{+2}$ were a consequence of their relatively slow cytotoxic reactions in the cells. Thus, as the toxicity developed, the observed 
TABLE III

Summary of Synergistic and Antagonistic Effects of Several Binary Cation Systems, 24-h Duration of Exposure

\begin{tabular}{lcc}
\hline Cations & Synergism & Antagonism \\
\hline $\mathrm{Ag}-\mathrm{Cu}$ & No & Yes \\
$\mathrm{Ag}-\mathrm{Ni}$ & Yes & Yes \\
$\mathrm{Ag}-\mathrm{Zn}$ & No & Yes \\
$\mathrm{Cu}-\mathrm{Cd}$ & Yes & No \\
$\mathrm{Cu}-\mathrm{Ni}$ & Yes & No \\
$\mathrm{Cu}-\mathrm{Zn}$ & Yes & Yes \\
$\mathrm{Ga}-\mathrm{Ni}$ & Yes & \\
\hline
\end{tabular}

Cations added together at $24 \mathrm{~h}$. Cell target: 6700 cells. Cell density: 20,300 cells $/ \mathrm{cm}^{2}$.

TC50 decreased with increased exposure duration. The disparity between the ${ }^{3} \mathrm{H}-\mathrm{Tdr}$ and MTT-f parameters may have also been a consequence of the ${ }^{3} \mathrm{H}$ Tdr exhibiting the earliest toxicity. However, as the cytotoxic response developed, these parameters may have equalized. If the cytotoxic response with $\mathrm{Ag}^{+1}$ and $\mathrm{Zn}^{+2}$ developed much more rapidly, it might explain both the constancy of the TC50 values over time and the lack of any difference between the ${ }^{3} \mathrm{H}$-Tdr and MTT-f parameters since the majority of the effect would have been observed at $24 \mathrm{~h}$.

Experiments which measured TC50 concentrations at 72-h exposure were performed at half the cell density $\left(6250\right.$ cells $\left./ \mathrm{cm}^{2}\right)$ of the 24 - and $48-\mathrm{h}$ exposure experiments $\left(12,500\right.$ cells $\left./ \mathrm{cm}^{2}\right)$. Although this situation was not ideal, it was necessary to ensure that confluence of the cell monolayer was prevented. Lower densities were not used for the 24- and 48-h experiments because of inadequate sensitivity in the toxicity parameters. It is possible that the $72-\mathrm{h}$ TC50 values were influenced by the reduced cell density, but these values agreed with trends established by the 24- and 48-h experiments. Growth rates at both cell densities were similar because confluence was not reached. Figure 2(a) supports the assumption that the change in cell density did not grossly influence the TC50 values. In this figure, the TC50 $0_{\mathrm{MTT}-\mathrm{f}}$ values for $\mathrm{Ag}^{+1}$ and $\mathrm{Cu}^{+2}$ alone were about 0.65 and $16 \mathrm{ppm}(6.0$ and $250 \mu \mathrm{M})$, respectively, at cell density of 20,300 cells $/ \mathrm{cm}^{2}$. These TC50 values agree with previously published values measured at a cell density of 16,000 cells $/ \mathrm{cm}^{2}$ (Table IV). Overall, we believe that the advantages of avoiding a confluent monolayer, which would have certainly influenced the experiments by changing the rate of cell division or cell metabolism, outweighed the disadvantages of adjusting the cell density.

In a previous study, the ranking of the potencies of several metal cations was shown to be a function of the parameter used to assess toxicity. ${ }^{14}$ The present study showed that rankings also depended upon the duration of exposure chosen for the assessment (Table II). This change in ranking demonstrates the importance of avoiding generalizations about the potencies of metal cations without specifically defining the conditions of the experiments used to assess them. It is likely that other conditions such as cell type influence these potencies as well. 
TABLE IV

Comparison of TC50 Values for Various Ions Using 24-h Durations of Exposure Starting at 0 and $24 \mathrm{~h}$

\begin{tabular}{|c|c|c|}
\hline \multirow[b]{2}{*}{ Cation } & \multicolumn{2}{|c|}{ Duration of Exposure } \\
\hline & $0-24 h^{a}$ & $24-48 h^{b}$ \\
\hline \multicolumn{3}{|l|}{$\mathrm{Ag}^{+1}$} \\
\hline MTT-f & 6.7 & 5.8 \\
\hline${ }^{3} \mathrm{H}-\mathrm{Td} \mathrm{r}$ & 6.2 & 6.2 \\
\hline \multicolumn{3}{|l|}{$\mathrm{Cd}^{+2}$} \\
\hline MTT-f & 3.7 & 1.1 \\
\hline${ }^{3} \mathrm{H}-\mathrm{Tdr}$ & 1.3 & 0.4 \\
\hline \multicolumn{3}{|l|}{$\mathrm{Cu}^{+2}$} \\
\hline MTT-f & 102 & 240 \\
\hline${ }^{3} \mathrm{H}-\mathrm{Td} \mathbf{r}$ & 14 & 44 \\
\hline \multicolumn{3}{|l|}{$\mathrm{Ga}^{+3}$} \\
\hline MTT-f & 29 & 200 \\
\hline${ }^{3} \mathrm{H}-\mathrm{Td} \mathrm{r}$ & 14 & 65 \\
\hline \multicolumn{3}{|l|}{$\mathrm{Ni}^{+2}$} \\
\hline MTT-f & 370 & 190 \\
\hline${ }^{3} \mathrm{H}-\mathrm{Td} \mathrm{r}$ & 190 & 190 \\
\hline \multicolumn{3}{|l|}{$\mathrm{Zn}^{+2}$} \\
\hline MTT-f & 35 & 28 \\
\hline${ }^{3} \mathrm{H}-\mathrm{Tdr}$ & 35 & 28 \\
\hline
\end{tabular}

${ }^{a}$ Data repeated from Table II for convenience.

'Data from J.C. Wataha, C.T. Hanks, and R.G. Craig, "The in vitro effects of metal cations on eucaryotic cell metabolism," J. Biomed. Mater. Res., 25, 1133-1149 (1991). Cell density $=16,000$ cells $/ \mathrm{cm}^{2}$.

The time of addition of the cation to the cells appeared to be important to the overall potency of the cations. Table IV compares the potencies of these cations with 0-h time of addition (data repeated from Table II for convenience) with those determined previously using a 24 -h time of addition. ${ }^{14}$ Both experiments used 24-h durations of exposure, yet there were many disparities among these values. Furthermore, there was no overall pattern to these disparities. $\mathrm{Ga}^{+3}$ and $\mathrm{Cu}^{+2}$ showed lower TC50 values, $\mathrm{Cd}^{+2}$ and $\mathrm{Ni}^{+2}$ showed higher values, and those for $\mathrm{Ag}^{+1}$ and $\mathrm{Zn}^{+2}$ were approximately the same. The cause of these differences are not known but may lie in the mechanisms by which each cation exerted its toxic effect.

The present study agrees with work done by Leirskar, who reported that the cytotoxic effects of $\mathrm{Cu}^{+2}$ and $\mathrm{Cd}^{+2}$ increased from 24 to $72 \mathrm{~h}$ using human epithelial cells (NCTC 2544), but did not report this effect for $\mathrm{Zn}^{+2} .6$ The current study found similar effects for other metal cations, but more accurately quantified this effect by using more concentrations and TC50 values.

It was clear from the current study that the combined toxicity of two metal cations did not necessarily exert their toxic effects independently, and that interactive effects among released metal cations must be considered when evaluating the in vitro cytotoxicity of materials. The combinations of metal cations were chosen because previous studies which showed that they occurred in in vitro testing of alloys ${ }^{4}$ and amalgams. ${ }^{6}$ The interactive effects observed did appear to be somewhat dependent on the element (Table III), but 
further study using additional combinations would be needed to support this observation. It seems likely that the interactive cytotoxic effects of two metal cations would depend both upon the cytotoxic character of each cation as well as interplay among the cations.

Synergistic and antagonistic effects generally occurred at concentrations below the TC50 concentrations of the individual cations. In the $\mathrm{Ag}^{+1}-\mathrm{Cu}^{+2}$ system, concentrations of $\mathrm{Cu}^{+2}$ of only $16 \mu \mathrm{M}(1 \mathrm{ppm})$ or less were sufficient to contribute to antagonistic effects [Fig. 2(c)] even though the TC50 of Cu is about $240 \mu \mathrm{M}$ (Table IV, 24-48-h column). This phenomenon must be considered when the cytotoxic effects of materials which release multiple components are evaluated. A biomaterial might be cytotoxic even though the concentrations of its released components are below accepted cytotoxic levels of the individual components. On the other hand, the cytotoxicity of one component near its TC50 concentration might be reduced by low concentrations of a second component.

Several variables probably influenced the synergistic and antagonistic effects observed. Both cations were added together in these experiments, but different effects might be observed if the times of addition of the two cations were different. The duration of exposure, type of cell, and cytotoxicity parameter which was measured might also influence the outcome. A more complete understanding of the mechanisms by which each cation as well as combinations of cations exert their cytotoxic effects might also be realized by manipulating these variables in this system.

We thank Susan Strawn and Jackie Dahlgren for their assistance during these investigations, and the NIDR for their support of this work through Grants 5 F32 DE05584 and 1 P50 DE09296.

\section{References}

1. J.S. Covington, M. A. McBride, W. F. Slagle, and A. L. Disney, "Quantization of nickel and beryllium leakage from base metal casting alloys," J. Prosthet. Dent., 54, 127-136 (1985).

2. V. Goehlich and M. Marek, "Corrosion behavior of Pd-Cu and Pd-Co alloys in synthetic saliva," Dent. Mater., 6, 103-110 (1990).

3. A.W. J. Muller, F. J. M. J. Maessen, and C. L. Davidson, "Determination of the corrosion rates of six dental NiCrMo alloys in an artificial saliva by chemical analysis of the medium using ICP-AES," Dent. Mater., 6, 63-68 (1990).

4. J.C. Wataha, R.G. Craig, and C.T. Hanks, "The release of elements of dental casting alloys into cell-culture medium," J. Dent. Res., 70, 10141018 (1991).

5. J. Geis-Gerstorfer, K. H. Sauer, and K. Pässler, "Ion release from Ni-CrMo and Co-Cr-Mo casting alloys," Int. J. Prosthodont., 4, 152-158 (1991).

6. J. Leirskar, "On the mechanism of cytotoxicity of silver and copper amalgams in a cell culture system," Scand. J. Dent. Res., 82, 74-81 (1974).

7. D. Brune, "Metal release from dental biomaterials," Biomaterials, 7, 163175 (1986).

8. T. Okabe, J. Ferracane, C. Cooper, H. Matsumoto, and M. Wagner, "Dissolution of mercury from amalgam into saline solution," J. Dent. Res., 66, 33-37 (1987). 
9. W. J. Peters, R.W. Jackson, K. Iwano, and D.C. Smith, "The biological response to zinc polyacrylate cement," Clin. Orthop., 88, 228-233 (1972).

10. M. Nourollahi and S.D. Meryon, "The antibacterial properties of four elements released from dental restorative materials," Int. Endod. J., 22, 9-16 (1989).

11. H. Kawahara, A. Yamagami, and M. Nakamura, "Biological testing of dental materials by means of tissue culture," Int. Dent. J., 18, 443-467 (1968).

12. M. Costa, "Levels of ornithine decarboxylase activation used as a simple marker of metal induced growth arrest in tissue culture," Life Sci., 24, 705-713 (1979).

13. H. Babich, C. Shopsis, and E. Borenfreund, "In vitro cy totoxicity testing of aquatic pollutants (cadmium, copper, zinc, nickel) using established fish cell lines," Ecotoxicol. and Environ. Safety, 11, 91-99 (1986).

14. J.C. Wataha, C.T. Hanks, and R.G. Craig, "The in vitro effects of metal cations on eucaryotic cell metabolism," J. Biomed. Mater. Res., 25, 11331149 (1991).

Received August 23, 1991

Accepted February 20, 1992 